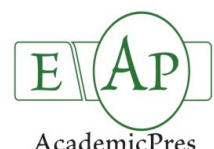

\title{
Gamma-ray Irradiation Induces Useful Morphological Variation in Bermudagrass
}

\author{
Songul SEVER MUTLU ${ }^{1 *}$, Haris DJAPO ${ }^{2}$, Suleyman F. OZMEN ${ }^{3}$, \\ Ceren SELIM ${ }^{1}$, Nina TUNCEL ${ }^{2}$ \\ ${ }^{1}$ University of Akdeniz, Faculty of Agriculture, Department of Landscape Architecture, 07070 Antalya, \\ Turkey;songulmuth@akdenizedu.tr("correspondingauthor);cerenselim@akdenizedu.tr \\ 2UniversityofAkdeniz,Faculty ofScience,DepartmentofPhysics,07058Antalya,Tunkey; haris@akdeniz.edu.tr;ninatuncel@akdenizedu.tr \\ ${ }^{3}$ University of Akdeniz, Technical Sciences,07058 Antalya, Turkey; fatihozmen@akdenizedu.tr
}

\begin{abstract}
Bermudagrass, Cynodon dactylon (L.) Pers. is a widely used warm-season turfgrass species in warmer regions of the world. Gamma ( $\mathrm{\gamma}$ ) irradiation has been used to generate useful variations in turfgrass breeding for various morphological traits. The objective of the present study was to measure and determine variations in morphology and turfgrass characteristics of a native drought resistant bermudagrass germplasm irradiated with 70, 90 or 110 Gy using a ${ }^{60} \mathrm{Co}$ source. The stolons containing a single node were irradiated and immediately planted for regeneration in a greenhouse at the Akdeniz University, Antalya, Turkey. Selected mutants regenerated from the irradiated stolons were clonally propagated and transplanted into plastic pots for further observations of turfgrass characteristics. Survival rates of stolons exposed to 70, 90 and 110 Gy were $76 \%, 43 \%$ and $17 \%$ respectively, 6 weeks after treatment. Dosages of 85 and 57 Gy were determined as $\mathrm{LD}_{50}$ and $\mathrm{LD}_{20}$ for the cuttings, respectively. The linear reduction of survival rate with increasing gamma-rays was highly correlated $\left(r^{2}=0.99\right)$. A total of four mutant lines ( $0.3 \%$ of the irradiated plants) showed a distinct dwarfed growth habit. Three of these lines were originated from 70 Gy and one from 110 Gy. These mutant lines exhibited more dwarf growth habit, higher shoot density, finer leaf texture than parental genotype. Mutant lines developed in this study can be used for the development of improved bermudagrass cultivars for landscaping and sports turf.
\end{abstract}

Keywords: breeding, dwarf mutants, ${ }^{60} \mathrm{Co}$, mutation, turfgrass

\section{Introduction}

Bermudagrass [Cynodon dactylon (L.) Pers.] is a warm-season grass widely used for pasture, forage, turfgrass, soil stabilization, and remediation (Burton, 1947; Taliaferro, 2003). Cynodon genotypes with all known ploidy levels exist in the eastern Mediterranean of Turkey (Gulsen et al., 2009). The tetraploid $C$. dactylon genotypes have been the sole genetic pool for development of seeded-type bermudagrass cultivars. Some of the native tetraploid C. dactylon genotypes collected from coastal Mediterranean region of Turkey possessed superior drought tolerance and darker green color than commercial bermudagrass cultivars (ex. 'Princess 77', 'Riviera') under Mediterranean conditions (Sever Mutlu et al., 2014).These wild germplasm of bermudagrass is well adapted to the region's biotic and abiotic factors. However, their rapid vertical growth, coarse-leaf texture and long internodes are undesirable and limit their use as turfgrass. Rapid, upright shoot growth requires frequent mowing and irrigation, increasing energy cost during active growing season (Chen et al., 2009). Dwarf bermudagrass mutants induced by gamma radiation exhibited enhanced drought resistance compared to their wild-type parents (Lu et al., 2008). Therefore, there is an increasing demand for slow-growing dwarf type turf cultivars with high drought resistance. Irradiation mutagenesis has been used to create genetic diversity in major crops. Ahloowalia and Maluszynski (2001) reported that more than 1800 released cultivars developed either as direct mutants or derived from their crosses worldwide. Mutation breeding has successfully been used in turfgrasses (Busey, 1980; Dickens et al., 1981; Burton, 1985; van Harten, 1998; Hanna and Elsner, 1999). Gamma-rays irradiation has also been successfully used to generate new breed lines of bermudagrass from the wild germplasm (Lu et al., 2009). Each of these mutant turf cultivars possessed finer texture and superior turgrass quality than their parental genotypes (Li et al., 2010). The most frequent mutant character from the irradiated plants is dwarfism (Powell et al., 1974). Many dwarf-type bermudagrass cultivars (ex. 'Tifway II', 
516

'TifEagle') were developed by gamma irradiation (Burton 1985; Hanna et al., 1997b; Hanna and Elsner 1999). The aim of this research was to induce dwarf mutants from native drought resistant bermudagrass genotypes to generate new breed lines/cultivars of bermudagrass. The mutant progenies with dwarf type growth habit, and superior turfgrass characteristics can be used in seeded-type $(4 \mathrm{x})$ bermudagrass breeding. The morphological traits and other turf characteristics of dwarf mutants induced by gamma irradiation in comparison to their parents were evaluated.

\section{Materials and Methods}

\section{Plant material and mutation treatment}

A local tetraploid bermudagrass genotype 'B-165'collected from Erzin-Hatay city Turkey, was used as the plant material (Gulsen et al., 2009). The 'B-165' exhibits dark green color and was determined to be highly drought resistant after a multiyear/environment evaluation under Mediterranean conditions (Sever Mutlu, unpublished data). However, it exhibited an undesirable rapid upright growth habit with coarser leaf texture compared to commercial bermudagrass cultivars. Stolons of 'B$165^{\prime}$ were collected from the mature field plot at Akdeniz University, Antalya, Turkey and attached soil was washed off with tap water. The stolons were cut into single node cuttings, placed in plastic petri dishes and irradiated with $0,70,90$ or 110 $\mathrm{Gy}$ doses of $\gamma$-radiation from ${ }^{60} \mathrm{Co}$ with a dose rate of approximately $35 \mathrm{~Gy} / \mathrm{h}$ at $100 \mathrm{~cm}$ source-to-sample distance. Each treatment consisted of 450 cuttings.

The control cuttings were not irradiated, but placed in petri dishes and kept in $5^{\circ} \mathrm{C}$ to maintain moisture until planting. After irradiation, the cuttings were immediately planted in the mixture of peat, vermiculite and perlite $(3: 1: 1, \mathrm{v} / \mathrm{v} / \mathrm{v})$ for regeneration in a greenhouse under natural light conditions on Feb 15, 2011. The 30 plants regenerated from the irradiated stolons with visible morphological changes compared to their respective wild-type plants were selected and transplanted into the plastic pots for further observation of growth and turf characteristics in Apr 2011. Among them, four mutant lines exhibiting dwarf characteristics with finer leaf texture, shorter canopy height than 'B-165' parental plants were chosen, and clonally propagated for detailed evaluation in Jun 2011.

Experimental design was a randomized complete block with 4 replications for each line. Plants were allowed to grow for 3 months in a greenhouse under natural light and at temperature of $25-35^{\circ} \mathrm{C}$. During the establishment period, plants were fertilized with $2.5 \mathrm{~g} \mathrm{~N} \mathrm{~m}^{-2}$ with $15 \mathrm{~N}-6.6 \mathrm{P}-12.5 \mathrm{~K}$, a complex fertilizer, biweekly and irrigated daily to prevent visual wilt symptoms and mowed at $5 \mathrm{~cm}$ weekly. The plants were maintained outside the greenhouse under full sun conditions from Oct 2011 to Feb 2012 to detect variations in color retention, dormancy and relative chlorophyll content in comparison to their parental germplasm in the fall.

Data collection and statistical analyses

Irradiation dosage effect on single node cuttings

Survival of the cuttings was scored 6 weeks after irradiation treatment. Survival rate was calculated as a percentage of cuttings with re-growth divided by the total number. The data-points obtained in this way were fitted to the probit function: $\operatorname{probit}(p)=a+b \sqrt{2} \operatorname{erf}^{-1}(2 \mathrm{p}-1)$ where $a$ is the y-intercept, $b$ is slope and $p$ is the normalized survival probability. The fit was performed by using the ROOT package (Brun, 1997). In addition an inverse fit was performed as a consistency check and for easy display of data. In all cases the probit-fit and the inverse fit agreed perfectly. The probit function can be easily used to determine any lethality dose (LD).

\section{Morphological characterization of mutant plant lines}

Canopy heights with and without seedhead measurements were made on five random plants for each pot. Longest leaf at third node below apical meristem on main upright tiller was used for the measurement of leaf length and leaf width. Seed head density was determined quantitatively by counting seed heads per pot. Five mature inflorescences were collected from each pot to determine the number of racemes per inflorescence, raceme length, seed head exertion from the base of the inflorescence to the flag leaf, and peduncle length. The measurements in each pot were made on five randomly selected stolons for internode length and diameter between $3^{\text {rd }}$ and $4^{\text {th }}$ fully extended nodes from apical meristem, stolon length from apical meristem to the $5^{\text {th }}$ node; and for total stolon number by counting stolons per pot. Visual assessment of leaf texture was an estimate of leaf width.

The visual ratings of texture, shoot density, fall color retention and fall/winter dormancy were collected as described by the National Turfgrass Evaluation Program (NTEP) (Morris, 2004). Five measurements were taken within each pot for relative chlorophyll content using a chlorophyll meter (Field Scout CM 1000; Spectrum Technologies, Inc., Plainfield, IL).

Treatment differences were tested using analysis of variance procedures with PROC GLM (SAS release 8.0; SAS Institute, Cary, NC). Means were separated using Fisher's protected least significant difference $(\mathrm{P}<0.05)$ procedure.

\section{Results}

Probit analysis indicated that $\mathrm{LD}_{50}$ and $\mathrm{LD}_{20}$ dosages were $85 \pm 7$ and $57 \pm 14 \mathrm{~Gy}$, respectively (Fig. 1). Survival rates of cuttings irradiated at 70, 90 and 110 Gy were $76 \%, 43 \%$ and $17 \%$, respectively. The linear reduction of survival rate with increasing $\gamma$-rays was highly negatively correlated $\left(\gamma^{2}=0.99\right)$. Irradiation of 1350 single-node cuttings resulted in four morphological mutants ( $0.3 \%$ of the total irradiated cuttings) with dwarf/semi dwarf growth habit. Three of these, 165-70-1, 165-70-5, and 165-70-6, were obtained from cuttings treated at $70 \mathrm{~Gy}$, and one mutant line, 165-110-1, at $110 \mathrm{~Gy}$. The mutant lines exhibited finer plant texture, a more dwarf habit and slower vertical growth than the wild type 'B-165' (Table 1). The mutant lines with and without seed heads, respectively, were $26 \%$ to $38 \%$, and $30 \%$ to $51 \%$ shorter than wild-type control.

The mutant lines exhibited significant morphological differences compared to wild type (Table 1). The leaf blade length reduced by $34 \%-46 \%$, and $28 \%$ in the lines generated by $70 \mathrm{~Gy}$ and $110 \mathrm{~Gy}$, respectively. The leaf blade width also narrowed by $25 \%$ to $31 \%$. The mutant lines had significantly finer leaf texture (6.0 to 7.5 rating scale) compared to coarse textured parental genotype (4.0). The stolon number was both increased by $42 \%$ (165-70-6) and decreased by $30 \%$ (165-1101). Stolon length was reduced by $27 \%$ to $42 \%$, and by $52 \%$ in mutant lines originated from $70 \mathrm{~Gy}$ and $110 \mathrm{~Gy}$, respectively. Stolon internodes were thinner and up to $31 \%$ and $54 \%$ shorter in mutant lines originated from $70 \mathrm{~Gy}$ and $110 \mathrm{~Gy}$. 
Table 1. Morphological characteristics of the dwarf mutant bermudagrass (C. dactylon) lines generated via $\gamma$-radiation

\begin{tabular}{|c|c|c|c|c|c|c|c|c|c|c|c|}
\hline \multirow[b]{2}{*}{ Traits $^{1}$} & \multicolumn{2}{|l|}{ Control } & \multicolumn{3}{|c|}{ Mutantbermudalines } & \multicolumn{4}{|c|}{ \%Difference from control } & \multirow[b]{2}{*}{$\begin{array}{c}\text { Lsd } \\
(\mathrm{p} \leq 0.05)\end{array}$} & \multirow[b]{2}{*}{$\mathrm{Sig}^{2}$} \\
\hline & 'B-165' & '165-70-1' & '165-70-5’ & $165-70-6$ & '165-110-1' & '165-70-1' & '165-70-5’ & $' 165-70-6$ & '165-110-1' & & \\
\hline $\mathrm{CH}(\mathrm{cm})$ & $15.4 a^{3}$ & $8.8 \mathrm{c}$ & $7.7 \mathrm{c}$ & $7.5 \mathrm{c}$ & $10.9 \mathrm{~b}$ & -43 & -50 & -51 & -29 & 1.48 & *** \\
\hline CHWS (cm) & $24.0 \mathrm{a}$ & $15.0 c$ & $17.5 \mathrm{~b}$ & $17.0 \mathrm{~b}$ & $17.7 \mathrm{~b}$ & -38 & -27 & -29 & -26 & 1.80 & *** \\
\hline $\mathrm{LW}(\mathrm{mm})$ & $3.0 \mathrm{a}$ & $2.2 \mathrm{~b}$ & $2.3 \mathrm{~b}$ & $2.1 \mathrm{~b}$ & $2.3 b$ & -28 & -25 & -31 & -25 & 0.06 & * \\
\hline $\mathrm{LL}(\mathrm{cm})$ & $10.2 \mathrm{a}$ & $5.5 \mathrm{c}$ & $6.7 \mathrm{~b}$ & $5.6 \mathrm{c}$ & $7.3 \mathrm{~b}$ & -46 & -34 & 44 & -28 & 0.86 & $* *$ \\
\hline $\mathrm{SN}$ & $3.3 \mathrm{~b}$ & $3.0 \mathrm{~b}$ & $3.0 \mathrm{~b}$ & $4.7 \mathrm{a}$ & $2.3 \mathrm{c}$ & -9 & -9 & 41 & -30 & 0.90 & $* *$ \\
\hline $\mathrm{SL}(\mathrm{cm})$ & $15.8 \mathrm{a}$ & $9.2 \mathrm{~b}$ & $11.5 b$ & $11.0 \mathrm{~b}$ & $7.6 \mathrm{bc}$ & -42 & -27 & -30 & -52 & 2.60 & $*$ \\
\hline $\mathrm{ID}(\mathrm{mm})$ & $1.32 \mathrm{a}$ & $1.09 \mathrm{~b}$ & $1.23 \mathrm{ab}$ & $1.17 \mathrm{ab}$ & $1.07 \mathrm{~b}$ & -17 & -7 & -11 & -19 & 0.20 & * \\
\hline $\mathrm{IL}(\mathrm{cm})$ & $3.5 \mathrm{a}$ & $2.9 \mathrm{ab}$ & $2.4 \mathrm{~b}$ & $28 \mathrm{~b}$ & $1.6 \mathrm{c}$ & -16 & -31 & -19 & -54 & 0.54 & $*$ \\
\hline SHD (no/pot) & $65 c$ & $28 \mathrm{~d}$ & $129 \mathrm{~b}$ & $71 \mathrm{c}$ & $206 a$ & -57 & 98 & 9 & 217 & 17.90 & *** \\
\hline $\mathrm{RN}$ & $4.4 \mathrm{~b}$ & $4.9 a$ & $4.7 \mathrm{ab}$ & $4.3 \mathrm{~b}$ & $5.0 \mathrm{a}$ & 10 & 6 & -2 & 13 & 0.38 & $*$ \\
\hline $\mathrm{RL}(\mathrm{cm})$ & $4.2 \mathrm{a}$ & $3.4 \mathrm{c}$ & $3.6 \mathrm{bc}$ & $3.9 \mathrm{ab}$ & $4.1 \mathrm{a}$ & -19 & -14 & -7 & -2 & 0.36 & * \\
\hline $\mathrm{SHE}(\mathrm{mm})$ & $41.2 \mathrm{a}$ & $22 \mathrm{~d}$ & $30.6 \mathrm{bc}$ & $35.1 \mathrm{~b}$ & $28.5 c$ & -47 & -26 & -15 & -31 & 4.90 & $* *$ \\
\hline $\mathrm{PL}(\mathrm{cm})$ & $10.0 \mathrm{a}$ & $7.0 \mathrm{~d}$ & $7.9 \mathrm{c}$ & $8.9 b$ & $8.1 \mathrm{c}$ & -30 & -22 & -12 & -19 & 0.40 & *** \\
\hline CHL1 & $250.9 c$ & $260.7 b$ & $264.4 b$ & $274.0 \mathrm{a}$ & $240.7 \mathrm{~d}$ & 4 & 5 & 9 & 4 & 9.00 & $* *$ \\
\hline CHL2 & $115.0 \mathrm{~b}$ & $131.7 \mathrm{a}$ & $119.5 \mathrm{~b}$ & $136.8 \mathrm{a}$ & $118.5 \mathrm{~b}$ & 15 & 4 & 19 & 3 & 8.50 & $* *$ \\
\hline $\mathrm{SD}$ & $4.8 \mathrm{c}$ & $7.5 \mathrm{a}$ & $6.3 b$ & $6.0 \mathrm{~b}$ & $6.5 b$ & 58 & 33 & 26 & 37 & 0.78 & $* *$ \\
\hline $\mathrm{T}$ & $4.0 \mathrm{~d}$ & $6.8 \mathrm{a}$ & $6.5 \mathrm{~b}$ & $6.5 b$ & $6.0 \mathrm{c}$ & -70 & -63 & -63 & -50 & 0.42 & *** \\
\hline $\mathrm{FD}(\%)$ & $60 a$ & $40 c$ & $50 \mathrm{~b}$ & $35 c$ & $55 \mathrm{ab}$ & -33 & -17 & 42 & -8 & 9.50 & * \\
\hline FCR & $4.5 \mathrm{~d}$ & $7 \mathrm{a}$ & $6.0 \mathrm{~b}$ & $6.5 \mathrm{ab}$ & $5.8 \mathrm{bc}$ & 56 & 33 & 44 & 28 & 0.59 & $* *$ \\
\hline
\end{tabular}

${ }^{1} \mathrm{CH}$-canopy height without seed head; CHWS-canopy height with seed head; LW-leaf blade width at third node below apical meristem; LL-leaf blade length at third node below apical meristem; SN-stolon number per pot; SL-stolon length; ID and IL-internode diameter and internode length measured from between $3^{\text {rd }}$ and $4^{\text {th }}$ fully extended nodes from apical meristem; SHD-seed head density-seed head number per pot; RN-number of racemes per inflorescence; RL-raceme length; SHE-seed head exertion from the base of the inflorescence to the flag leaf; PL-peduncle length as the measurement of internode from base of whorl to first node; CHL1 and CHL2relative chloropyll content on 19 Oct 2011 and 4 Dec 2011, respectively; SD-shoot density rated on a 1 to 9 scale with 9 equaling maximum density; T-leaf texture rated on a 1 to 9 rating scale with 1 equaling coarse and 9 equaling fine texture; FD-fall/winter dormancy rated on $0-100 \%$ scale with 100 equaling complete dormancy, with straw brown colour of entire leaves on 4 Dec 2011 ; FCR-Fall colour retention, rated on a 1 to 9 visual rating scale with 1 equaling straw brown or no colour retention, and 9 equaling dark green on 20 Nov 2011.

$2 * * *, * * *:$ : significant at probability of $0.05,0.01$ and 0.001 , respectively.

${ }^{3}$ Values followed by the same letter within a trait were not significantly different from each other according to the $\operatorname{LSD}(\mathrm{P}=0.05)$.

Table 2. Correlation coefficients among morphological traits of mutant bermudagrass (C. dactylon) lines generated via $\gamma$-radiation

\begin{tabular}{|c|c|c|c|c|c|c|c|c|c|c|c|c|c|c|c|c|c|c|}
\hline Traits $^{1}$ & ID & SL & SN & $\mathrm{RN}$ & RL & SHD & SHE & PL & LL & LW & $\mathrm{CH}$ & CHWS & CHL 1 & CHL2 & SD & $\mathrm{T}$ & FD & FCR \\
\hline IL & $0,51^{* 2}$ & $0,65^{* *}$ & $n s^{3}$ & $-0,56^{* *}$ & $\mathrm{~ns}$ & $-0,78^{* *}$ & ns & ns & ns & $0,48^{*}$ & ns & ns & $\mathrm{ns}$ & $\mathrm{ns}$ & $-0,50^{*}$ & $\mathrm{~ns}$ & ns & ns \\
\hline ID & - & $0,49^{*}$ & ns & ns & ns & ns & $0,46^{*}$ & ns & ns & ns & ns & $0,52^{*}$ & ns & ns & $-0,53^{*}$ & $-0,48^{*}$ & ns & $-0,49^{*}$ \\
\hline SL & & - & ns & $-0,71^{* *}$ & $\mathrm{~ns}$ & ns & $0,69^{* *}$ & $0,71^{* *}$ & $0,67^{* *}$ & $0,63^{*}$ & $0,57^{*}$ & $0,74^{* *}$ & ns & ns & $-0,68^{* *}$ & $-0,67^{* *}$ & ns & $-0,72^{* *}$ \\
\hline SN & & & - & $-0,49^{*}$ & ns & ns & ns & $\mathrm{ns}$ & $\mathrm{ns}$ & ns & ns & $\mathrm{ns}$ & $0,62^{*}$ & $0,61^{*}$ & ns & $\mathrm{ns}$ & ns & ns \\
\hline $\mathrm{RN}$ & & & & - & $\mathrm{ns}$ & ns & $-0,57^{*}$ & $-0,57^{*}$ & ns & ns & ns & ns & $-0,55^{*}$ & ns & $0,50^{*}$ & ns & ns & ns \\
\hline RL & & & & & - & ns & $0,69^{* *}$ & $0,77^{* *}$ & $0,64^{*}$ & ns & $0,63^{*}$ & $0,68^{* *}$ & ns & ns & $-0,58^{*}$ & $-0,71^{* *}$ & $0,45^{*}$ & $-0,64^{*}$ \\
\hline SHD & & & & & & - & ns & ns & ns & ns & ns & ns & $-0,53^{*}$ & ns & ns & ns & ns & ns \\
\hline SHE & & & & & & & - & $0,96^{* *}$ & $0,66^{* *}$ & ns & $0,52^{*}$ & $0,81^{* *}$ & $\mathrm{~ns}$ & ns & $-0,83^{* *}$ & $-0,73^{* *}$ & ns & $-0,71^{* *}$ \\
\hline PL & & & & & & & & - & $0,75^{* *}$ & $0,55^{*}$ & $0,65^{* *}$ & $0,86^{* *}$ & ns & ns & $-0,84^{* *}$ & $-0,83^{* *}$ & $0,44^{*}$ & $-0,79^{* *}$ \\
\hline LL & & & & & & & & & - & $0,79^{* *}$ & $0,92^{* *}$ & $0,93^{* *}$ & $-0,57^{*}$ & $-0,63^{*}$ & $-0,75^{* *}$ & $-0,92^{* *}$ & $0,82^{* *}$ & $-0,92^{* *}$ \\
\hline LW & & & & & & & & & & - & $0,71^{* *}$ & $0,71^{* *}$ & ns & $-0,47^{*}$ & $-0,68^{* *}$ & $-0,73^{* *}$ & $0,55^{*}$ & $-0,64^{* *}$ \\
\hline $\mathrm{CH}$ & & & & & & & & & & & 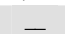 & $0,84^{* *}$ & $-0,65^{* *}$ & $-0,50^{*}$ & $-0,59^{*}$ & $-0,94^{* *}$ & $0,69^{* *}$ & $-0,81^{* *}$ \\
\hline CHWS & & & & & & & & & & & & - & ns & $-0,54^{*}$ & $-0,81^{* *}$ & $-0,93^{* *}$ & $0,69^{* *}$ & $-0,94^{* *}$ \\
\hline CHL 1 & & & & & & & & & & & & & - & $0,59^{*}$ & ns & $0,49^{*}$ & $-0,71^{* *}$ & $0,45^{*}$ \\
\hline CHL2 & & & & & & & & & & & & & & - & $0,45^{*}$ & $0,50^{*}$ & $-0,72^{* *}$ & $0,67^{* *}$ \\
\hline SD & & & & & & & & & & & & & & & - & $0,77^{* *}$ & $-0,49^{*}$ & $0,78^{* *}$ \\
\hline $\mathrm{T}$ & & & & & & & & & & & & & & & & - & $-0,60^{*}$ & $0,88^{* *}$ \\
\hline FD & & & & & & & & & & & & & & & & & - & $-0,7^{* *}$ \\
\hline
\end{tabular}
number per pot; RN-number of racemes per inflorescence; RL-raceme length; SHD-seed head density, number of seed head per pot; SHE-seed head exertion from the base of the inflorescence to the flag leaf; PL-peduncle length as the measurement of internode from base of whorl to first node; LL and LW-leaf blade length and leaf blade width at third node below apical meristem; CH-canopy height without seed head; CHWS-canopy height with seed head; CHL1 and CHL2-relative chlorophyll content on 19 Oct 2011 and 4 Dec 2011, respectively; SD-shoot density rated on a 1 to 9 scale with 9 equaling maximum density; T-leaf texture rated on a 1 to 9 rating scale with 1 equaling coarse and 9 equaling fine texture; FD-fall/winter dormancy rated on $0-100 \%$ scale with 100 equaling complete dormancy, with straw brown colour of entire leaves on $4 \mathrm{Dec} 2011$; FCR-fall colour retention, rated on a 1 to 9 visual rating scale with 1 equaling straw brown or no colour retention, and 9 equaling dark green on 20 Nov 2011

${ }^{2 *}, * *$ : significant at probability of 0.05 and 0.01 , respectively.

${ }^{3}$ ns: non-significant at probability of 0.05 .

Significant changes in inflorescence characteristics were also observed in mutant lines (Table 1). Compared to wild-type, seed head density both reduced by $57 \%$ and increased threefold in mutant lines. The number of racemes per inflorescence increased up to $13 \%$, and raceme length shortened up to $19 \%$. In addition, the peduncle length and seed head exertion from the base of the inflorescence to the flag leaf were reduced in all mutant lines. Highest reduction in peduncle length (\% 30) and seed head exertion (\% 47) was identified in mutant line '165-70-1'.
The mutant lines showed up to $58 \%$ higher shoot density. There was significant variation between mutant lines and control plants in terms of dormancy, relative chlorophyll content and color retention in late fall/winter period. Mutant lines retained their green color $28 \%$ to $56 \%$ better and developed up to $55 \%$ less dormancy in fall. Relative chlorophyll contents of mutant lines were up to $19 \%$ higher. Improvement in fall/winter performances as demonstrated by lower dormancy, higher chlorophyll content and darker green color in late fall was especially evident in mutant 
518

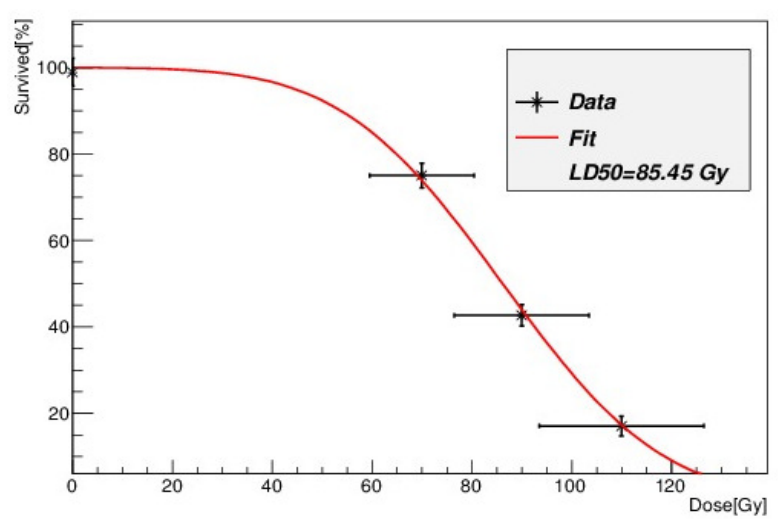

Fig. 1. Gamma ray dosage effects on survival of single-node bermudagrass cuttings ('B-165')

lines 165-70-1 and 165-70-6 (Table 1).

Correlation coefficients among morphological traits are presented in Table 2 . The relatively high correlations between shoot density and fall color retention $(r=0.78)$, and shoot density and texture $(r=0.77)$ reflected opportunity for spontaneous selection for the traits. Shoot density was also negatively correlated with internode length $(r=-0.50)$, diameter $(r=-0.53)$, stolon length $(r=-0.68)$, peduncle length $(r=-0.84)$, leaf length $(\mathrm{r}=-0.75)$, leaf width $(r=-0.68)$, seed head density $(r=-0.83)$, and canopy height $(r=-0.59)$. Therefore, selection for plants with shorter lengths of internode, stolon, leaf blade, raceme, and peduncle, and shorter canopy height and thinner internode diameter and narrower leaf blade should increase shoot density and concurrently improve leaf texture. The canopy height was positively correlated with stolon length $(r=0.57)$, leaf length $(r=0.92)$, leaf width $(r=0.71)$, peduncle length $(r=0.65)$, and raceme length $(\mathrm{r}=0.63)$; and negatively with leaf texture $(\mathrm{r}=$ $0.94)$, shoot density $(\mathrm{r}=-0.59)$, fall color retention $(\mathrm{r}=-0.81)$, and chlorophyll content $(\mathrm{r}=-0.65)$. Results indicate that plants with shorter stolon, leafblade, raceme and peduncle, and narrower leaf blade exhibit more dwarf growth habit which in turn exhibits denser, finer textured turf with higher chlorophyll content and better fall color retention.

\section{Discussion}

Increasing $\gamma$-ray dosage significantly reduced survival rates $\left(r^{2}=0.99\right)$ in bermudagrass. Similar results were reported with other species of Poaceae family (Busey, 1980; Krishna et al., 1984; Hase et al., 1999; Zaka et al., 2002). Results showed that gamma irradiation doses of 70 to 113 Gy were successful in creating bermudagrass mutants, concurring with earlier reports (Powel et al., 1974; Burton, 1985; Hanna et al., 1997b; Caetano-Anolles, 1999; Hanna and Elsner, 1999; Lu et al., 2009). Four dwarf mutant bermudagrass lines $(0.3 \%)$ were obtained, comparable to $0.4 \%$ dwarf bermudagrass and St. Augustinegrass [Stenotaphrum secundatum (Walt.) Kuntze] mutants reported by Lu et al., (2009) and (Li et al., 2010), respectively. Dwarfisms have been associated with defection in biosynthesis or reception of gibberellins (Ross et al. 1997), brassinosteroids (Noguchi et al. 1999), and regulation of cell elongation (Takahashi et al. 1995) or with abnormal cell walls (Reiter et al., 1993).
The LD50 dose was determined to be 85 Gy. Bermudagrass exerted a higher tolerance to gamma irradiation compared to St. Augustinegrass (30- 48.5 Gy) (Busey, 1979; Li et al., 2010). The most dwarf mutant line was $51 \%$ shorter, similar to $55 \%$ reduction in bermudagrass (Lu et al., 2009), and to $31-84 \%$ reduction in other species of grass family (Cheema and Atta, 2003; Al-Salhi et al., 2004; Borzouei et al., 2010; Nasab et al., 2010; Kim et al., 2015). Reduction in canopy height and slowgrowing trait in dwarf lines may further improve drought resistance over parental genotype. Reports by Lu et al. (2008) and Chen et al. (2009) demonstrated enhanced drought resistance of dwarf mutants compared to their wild type parents, probably due to reduced leaf area. Studies with bentgrasses (Agrostis sp.) also indicated that slow-growing turfgrass may be able to survive drought stress for prolonged periods of time (DaCosta and Huang, 2006, 2007).

Useful morphological variations were created by $\gamma$-radiation. The bermudagrass mutants had higher shoot density and finer plant texture with significantly smaller leaves and shortened internodes and stolons. As a result of gamma radiation, shorter internodes and smaller leaves were reported in bermudagrass (Hanna, 1990; Chen et al., 2009; Tiwari et al., 2014), centipedegrass [Eremochloa ophiuroides (Munro) Hack.] (Pedersen and Dickens, 1985; van Harten, 1998) and St.Augustinegrass (Powell and Toler, 1980; Reynolds et al., 2009; Li et al., 2010); and enhanced shoot/tiller density in wheat (Triticum aestivum L.) and barley (Hordeum vulgare L.) (Breslavets, 1946), and purple false brome (Brachypodium distachyon) (Kim et al., 2015). The turfgrass quality is associated with compact growth pattern and finer leaves (Reynolds et al., 2009). Superior turfgrass quality of dwarf lines was also reported with other studies using gamma radiation in the development of dwarf cultivars of bermudagrass (Burton, 1985; Hanna et al., 1997b; Hanna and Elsner, 1999; Tiwari et al., 2014), St.Augustinegrass (Busey, 1980; Reynolds et al., 2009) and centipedegrass (Dickens et al., 1981).

High variations in inflorescence characteristics were found between mutant lines and wild type parent. Among the dwarf mutants, 165-110-1, generated from 110 Gy is particularly interesting since it produced threefold more inflorescences with $13 \%$ increase in raceme number per inflorescences. Enhanced panicle length and number in rice (Oryza sativa L.) (Maity et al., 2005), and nearly eightfold more inflorescences in St. Augustinegrass were reported ( $\mathrm{Li}$ et al., 2010) among the mutants. Wu et al. (2006) reported that inflorescence prolificacy had $51 \%$ positive correlation on seed yield, indicating that selection for increased inflorescence prolificacy would be one of the best indirect selection traits for improvement of seed yield in bermudagrass. Mutant line '165-110-1'would enlarge the germplasm pool of bermudagrass and serve as a good breeding material to enhance seed yield.

The mutant lines exhibited better fall performance in comparison to the wild-type control, as manifested by better green color retention in conjunction with higher relative chlorophyll content and lower dormancy. Chlorophyll content is one of the important parameter reflecting the ability of plants to withstand stress. Dwarf mutant lines developed through gamma radiation with enhanced chlorophyll content, chilling and drought tolerance have been reported in Stylosanthes guianensis (Tan et al., 2009). 
New genetic variations generated by mutation breeding are particularly advantageous in improving an already outstanding genotype (Busey, 1977;Ahloowalia and Maluszynski, 2001) such as 'Tifsport', a fine-textured mutant bermudagrass, developed from a coarse-textured cold hardy cultivar 'Midiron' (Hanna et al., 1997b). Moreover, 'Tifsport' has been reported to have significantly higher turfgrass quality than 'Midiron' with sufficient cold tolerance (Taliaferro, 2003). The genotype 'B$165^{\prime}$ used as parent in the present study has excellent drought resistance but its coarse texture and rapid upright growth habit were undesirable. Similarly, the dwarf mutant lines generated from 'B-165' exhibited finer plant texture with slower vertical growth. Otherwise, transferring the high drought resistance of 'B-165' into commercially acceptable dwarf type background would have required lengthy phenotypic recurrent selections. Because the mutant lines derived from the drought resistant line 'B-165', they potentially bear a comparable drought resistance. Thus, evaluation of the mutants for drought resistance would be a necessary step to see whether or not they retained this important trait.

\section{Conclusions}

The results showed that dwarf mutants of bermudagrass generated through gamma irradiation induced mutation had higher shoot density, finer plant texture and exhibited better fall performance compared to the wild-type control. The lines can be used for the development of improved bermudagrass cultivars for landscaping and sports turf.

\section{References}

Ahloowalia BS, Maluszynski M (2001). Induced mutations a new paradigm in plant breeding. Euphytica 118:167-173.

AlSalhi M, Ghannam MM, Al-Ayed MS, El-Kameesy SU, Roshdy S (2004). Effect of gamma-irradiation on the biophysical and morphological properties of corn. Nahrung-Food 48(2):95-98.

Ayala-Silva T, Schnell RJ, Meerow AW, Winterstein M, Cervantes C, Brown JS (2005). Determination of color and fruit traits of half-sib families of mango (Mangifera indica L.). Proceedings of Florida State Horticultural Society 118:253-257.

Borzouei A, Kafi M, Khazaei H, Naseriyan B, Majdabad A (2010). Effects of gamma radiation on germination and physiological aspects of wheat (Triticum aestivum L.) seedlings. Pakistan Journal of Botany 42(4):2281-2290.

Breslavets P (1946). Plants and X-rays. Academy of Science, U.S.S.R. Press, Moscow.

Brun R, Rademakers F (1997). ROOT - An object oriented data analysis framework. Nuclear Instruments and Methods in Physics Research Section A: Accelerators, Spectrometers, Detectors and Associated Equipment 389:81-86.

Burton GW (1947). Breeding bermudagrass for the southeastern United States. Journal of the American Society of Agronomy 39:551-569.

Burton GW (1985). Registration of Tifway II bermudagrass. Crop Science 25:364.

Busey P (1977). Turfgrasses for the 1980's. Proceedings of Florida State Horticultural Society 90:111-114.
Busey P (1980). Gamma ray dosage and mutation breeding in St. Augustine grass. Crop Science 20: 81-184.

Caetano-Anolles G (1999). High genome-wide mutation rates in vegetatively propagated bermudagrass. Molecular Ecology 8:12111221.

Cheema AA, Atta BM (2003). Radiosensitivity studies in basmati rice. Pakistan Journal of Botany 40(2):605-613.

Chen C, Lu S, Chen Y, Wang Z, Niu Y, Guo Z (2009). A gamma-rayinduced dwarf mutant from seeded bermudagrass and its physiological responses to drought stress. Journal of the American Society for Horticultural Science 134(1):22-30.

Dickens R, Johnston WJ, Haaland RL (1981). Variability observed in centipede grass grown from ${ }^{60} \mathrm{Co}$ irradiated seed. Agronomy Journal 73:674-676.

DaCosta M, Huang B (2006). Osmotic adjustment associated with variation in bentgrass tolerance to drought stress. Journal of the American Society for Horticultural Science 131:338-344.

DaCosta M, Huang B (2007). Changes in antioxidant enzyme activities and lipid peroxidation for bentgrass species in response to drought stress. Journal of the American Society for Horticultural Science 132:319-326.

Gulsen O, Sever Mutlu S, Mutlu N, Tuna M, Karaguzel O, Shearman RC, Riordan, TP, Heng-Moss TM (2009). Polyploidy creates higher diversity among Cynodon accessions as assessed by molecular markers. Theoretical and Applied Genetics 118:1309-1319.

Hanna WW (1990). Induced mutations in Midiron and Tifway bermudagrasses. Agronomy abstracts. American Society of Agronomy, San Antonio, Texas. pp175.

Hanna WW, Dobson J, Duncan RR, Thompson D (1997a). Registration of 'TifBlair' centipedegrass. Crop Science 37:1017.

Hanna WW, Carrow RN, Powell AJ (1997b). Registration of 'Tift 94' bermudagrass. Crop Science 37:1012.

Hanna WW, Elsner JE (1999). Registration of TifEagle bermudagrass. CropScience 39:1258.

Hase $\mathrm{Y}$, Shimono $\mathrm{K}$, Inoue $\mathrm{M}$, Tanaka A, Watanabe $\mathrm{H}$ (1999).Biological effects of ion beams in Nicotiana tabacum L. Radiation and Environmental Biophysics 38:111-115.

Kim JY, Na CS, Kim DS, Kim J, Seo YW (2015). The effect of chronic gamma ray irradiation on lignocellulose of Brachypodium distachyon. Cellulose 22:2419-2430.

Krishna G, Shivashankar G, Nath J (1984). Mutagenic response of rhodes grass (Chloris gayana Kunth.) to gamma rays. Environmental and Experimental Botany 24(2):197-205.

Li R, Bruneau AH, Qu R (2010). Morphological mutants of St.Augustinegrass induced by gamma ray irradiation. Plant Breeding 129:412-416.

Lu S, Wang Z, Niu Y, Guo Z, Huang B (2008). Antioxidant responses of radiation-induced dwarf mutants of bermudagrass to drought stress. Journal of the American Society for Horticultural Science 133(3):360-366.

Lu S, Wang Z, Niu Y, Chen Y, Chen H, Fan Z,... Li H (2009). Gamma-ray radiation induced dwarf mutants of turf-type bermudagrass. Plant Breeding 128:205-209. 
520

Maity JP, Mishra D, Chakraborty A, Saha A, Santra SC, Chanda S (2005). Modulation of some quantitative and qualitative characteristics in rice (Oryza sativa L.) and mung (Phaseolus mungo L.) by ionizing radiation. Radiatian Physics and Chemistry 74:391-394.

Morris K (2004). A guide to NTEP turfgrass ratings. 15 Sep. 2015. <http://www.ntep.org/reports/ratings.htm\#quality>

Nasab SS, Sirchi GRS, Torabi-Sirchi MH (2010). Assessment of dissimilar g-irradiations on barley (Hordeum vulgare spp.). Journal of Plant Breeding and Crop Science 2:59-63.

Noguchi T, Fujioka S, Choe S, Takatsuto S, Yoshida S, Yuan H,... Tax FE (1999). Brassinosteroid-insensitive dwarf mutants of Arabidopsis accumulate brassinosteroids. Plant Physiology 121(3):743-752.

Pedersen JF, Dickens R (1985). Registration of AU Centennial centipedegrass. Crop Science 25:364.

Powell JB, Burton GW, Young JR (1974). Mutation induced in vegetatively propagated turf bermudagrass by gamma radiation. Crop Science 14(2):327-333.

Powell JB, Toler RW (1980). Induced mutants in Floratam St. Augustinegrass. Crop Science 20:644-646.

Reiter WD, Chapple CCS, Somerville CR (1993): Altered growth and cell walls in a fructose-deficient mutant of Arabidopsis. Science 261:1032-1035.

Reynolds WC, Li R, de Silva KA, Bruneau H, Qu R (2009). Field performance of mutant and somaclonal variation lines of St. Augustinegrass [Stenotaphrum secundatum (Walt.) Kuntze]. International Turfgrass Society Research Journal 11:573-582.

Ross J, Murfet IC, Reid JB (1997). Gibberellin mutants. Physiologia Plantarum 100:550-560.
Sever Mutlu S, Mutlu N, Selim C, Hocagil MM (2014). Broadening the genetic base of bermudagrass. European Journal of Horticultural Science 79(3):183-194.

Takahashi T, Gasch A, Nishizawa N, Chua NH (1995).The DIMINUTO gene of Arabidopsis is involved in regulating cell elongation. Genes and Development 9:97-107.

Taliaferro CM (2003). Bermudagrass (Cynodon (L.) Rich). In: Casler MD, Duncan RR (Eds). Turfgrass Biology, Genetics, and Breeding. John Wiley \& Sons Inc Hoboken, NJ pp 235256.

Tan J, Tang H, Niu Y, Chen Y, Lu S, Guo Z, Li H (2009). Isolation and characterization of gamma radiation-induced dwarf mutants of Stylosanthes guianensis. Tropical Grasslands 43:53-61.

Tiwari, AK, Kumar R, Kumar G, Kadam GB, Saha TN, Girish KS, Tiwari $B(2014)$. Mutagenesis and digital image analysis of mutants for quality attributes of native Cynodon dactylon. Indian Journal of Agricultural Sciences 84(6):733-736.

van Harten AM (1998). Mutation Breeding: theory and practical applications. Cambridge Univ Press, Cambridge, UK.

Wu YQ, Taliaferro CM, Martin DL, Goad CL, Anderson JA (2006). Genetic variability and relationships for seed yield and its components in Chinese Cynodon accessions. Field Crops Research 98:245-252.

Zaka, R, Vandecasteele, CM, Misset MT (2002). Effect of low chronic doses of ionizing radiation on antioxidant enzymes and G6PDH activities in Stipa capillata (Poaceae). Journal of Experimental Botany 53(376):1979-1987. 